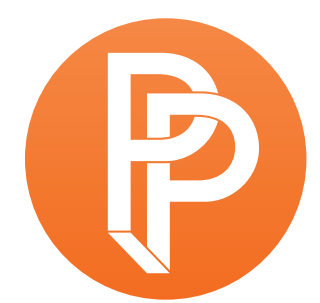

PERFORMANCE

PHILOSOPHY

\title{
ALTERING BODIES: THINKING OF INTERVENTION THROUGH IMPERSONATION
}

\author{
NIKI HADIKOESOEMO KU LEUVEN, BELGIUM
}

Introduction

Plato's Ion (C. 413 BCE) is arguably one of the earliest philosophical works in the Western tradition to examine the intoxicating effects of performance (Nails 2002, 175-176; Plato 2007, 1-4 and 2014; Rijksbaron 2007). At first glance, Ion's rhapsodic performance, which consists mainly in reciting Homer's Iliad and Odyssey, is put on display by Socrates in order to secure a philosophical argument regarding the absence of knowledge in the creation and interpretation of poetry (see Nagy 2009). According to Socrates, Ion lacks both theoretical (epistēmē) and practical knowledge, skill, or craft (tekhne). Instead, Ion's success is the result of divine inspiration and possession (enthusiasm), transmitted through the workings of the Muse. Consequently, in context of the ideal Greek society that Socrates has in mind, the rhapsodist is placed on the same bench as the poets in so far as both practices endanger the quest for systematic, theoretical knowledge and truth.

On second glance, although not necessarily contradicting the first reading, the lon discusses the conditions of performative intoxication in terms of questioning its limits and possibilities, and of deliberating its effects on performer and spectator. This perspective by-passes Socrates' ideal of theoretical inquiry with respect to performing altogether because it is based on a distinctive rhapsodic craft that Ion acknowledges but that Plato's character, Socrates, does not (want to) consider. While both perspectives are acknowledged and discussed by scholars, the second 
reading of the Ion is still largely underexposed. Therefore, the quest for the experiential foundations of rhapsodic crafting as well as its inherent critical potential remains generally untouched with respect to the Ion specifically. This article foregrounds the second approach in light of developing an account of performative intoxication as a strategy for critical intervention. By taking Ion's 'own', first-person perspective as its starting point, we see that the figure of the rhapsode is not necessarily and solely passively subjected to the Muse's doings, as Socrates claims. Rather, he masters the craft of using his intoxicated and intoxicating appearance in order to display and subvert what Philippe Lacoue-Labarthe calls "the comedy of the world" (Lacoue-Labarthe 1989, 264).

Instead of making general claims about what the lon fundamentally is about, this article aims to address an ancient problem that appears as a recurring theme in Western thought and gains interest in contemporary debates concerning performance and immanence (Cull 2012; Rokem 2017); namely, theatrical mimesis as an embodied, non-representational concept (Gebauer and Wulf 1995; Murray 1997; Potolsky 2006) and the anthropological notion of imitation as contagion and intoxication (Girard 1974; Nancy 2015; Tarde 2010). In that context, Plato's Ion is placed precisely at the tension point between philosophy and literature, embodying "the ancient quarrel between philosophy and poetry" (see also Corby 2015; Plato 2013a), hovering between the intoxicating power of performance and the quest for critical reasoning.

Martin Puchner's Drama of Ideas: Platonic Provocations in Theatre and Philosophy (2010) made a significant contribution in that regard by foregrounding the continuity of Platonic thought in drama. This article owes much to Drama of Ideas and takes cues from Puchner's suggestion to look beyond the seeming "anti-theatricality" of philosophical texts in general and Plato's Ion more specifically (Barish 1985; Rozzoni 2013, 120). Puchner argues that Plato's critique of Greek tragic theatre, comedy, actors and poets should be considered as an intrinsic component of his own philosophical style of reasoning:

\section{His critique, however, must be understood not as that of an outsider but as that of a rival; he was not an enemy of theater but a radical reformer. Attacking many features of Athenian theater, he sought to create an alternative form of drama, the Socratic dialogue. (Puchner 2010, 5)}

My reading of the Ion complements Puchner's account of philosophical thought with a corporeal component: taking the performer (Ion) as a starting point entails taking seriously the physical implications of conveying thought via forms of impersonation. Performing qua intoxicating does not refer to the transmission of thought only but also, and perhaps even more importantly, the transference of affect and emotion. In my view, what must be considered with respect to the practice of impersonation as a potentially critical tool is the quest for what it means for an embodied subject to impersonate and, correlatively, how that relates to affecting the body of the audience. After all, how can one account for intervention if one does not experience something as rupture (of thought, habit, normality, etc.)? This embodied approach will guide us in discussing the following questions. Is performative intoxication referring to a passive or active state? How does the actor's intoxication differ from the audience's? What relation between passivity and activity do 
we have to presuppose in order for an intoxicating practice to result in intervention? Why is impersonation the intoxicating practice par excellence to provoke catharsis as well as critique?

I will assess these questions by starting with a detailed account of lon's intoxicated and intoxicating nature. According to Socrates, Ion is so successful in portraying Homer's poetic verses because (a) he is intoxicated by his Muse, receiving his power directly from the divine, and (b) he is in turn able to intoxicate his audience through passive transmission. I will discuss this problematic on the basis of Socrates' analogy with the Heraclean lodestone as it explains intoxication as equally an activating, productive, and empowering mechanism. Moreover, it highlights lon's paradox of performing: he is possessed yet in control; he is passionately affected by Homer's verses but manages to masterfully direct the crowd with the nuances of his voice; he is a mere stand-in while being an expert in his field; he is in a state of pure exaltation yet he does not lose himself in trance or hysteria. In other words, passive and active forces seem to be paradoxically intertwined in the act of performing.

Secondly, I will turn to Denis Diderot's famous paradox of the actor-"it is just because he is nothing that he is before all everything" (Diderot 1957, 41)-in order to reevaluate Ion's paradox in a modern context. There are astonishing similarities between the apparent contradictions at play in Ion's performing and Diderot's account of the actor's practice, especially considering the 2000-year gap between the historical Socrates and Diderot. According to Diderot, it is because the actor is capable of keeping a clear head while being possessed, that he reaches the genius of the greatest philosophers (Diderot 1957, 18, 46). If the ancient rhapsode is "held" by his Muse, what is Diderot's actor infatuated by? And how does it allow for grounded critique? In order to understand what Diderot has in mind we have to briefly sketch out three central points of his original thesis: the problem of sensibility (sensibilité), the creation of an ideal imaginary model (le modèle idéal imaginé) and the importance of judgement (jugement). I will discuss these issues respectively and directly in relation to lon's rhapsodic performing, which provides the conceptual basis for what the twentieth century French philosopher and literary critic Philippe Lacoue-Labarthe will help us to develop further in the final part of this essay, namely to regard the actor's paradox as that which undermines the passive / active opposition, on the basis of which the logos (i.e. theatre) of the world operates. The figure of the actor doubles the theatre framework, that is, he/she intervenes by creating a theatre within a theatre. With the use of his/her impersonating skills, the actor is in the unique position to exhibit, ridicule and critique playfully the world's theatre of intoxication.

\section{Ion, the Heraclean magnet and performance as possession}

One entry into Socrates' account of the figure of the rhapsode is Socrates' own 'poetic move' in the Ion. Anticipating an argument by analogy, Socrates introduces somewhere in the middle of the dialogue the metaphor of the Heraclean magnet. The ancients often used the metaphor of the lodestone in order to explain the magnetism involved in divine inspiration. For example, the god Apollo intervenes in the poet's creation by providing his knowledge and power to the Muse, who will transmit that knowledge by inspiring the poet (Klooster 2011, 223). A magnetic force links Apollo with the Muse and the poet, much like how a lodestone attracts iron rings. Socrates argues 
that, in the same way as the poet, the rhapsode is intoxicated by his Muse: "For, as I was saying just now, this is not an art [tēkhne] in you, whereby you speak well on Homer, but a divine power, which moves you like that in the stone which Euripides named a magnet, but most people call 'Heraclea Stone'"' (Plato 2014, 533d). Socrates understands rhapsodic performance not as art or craft [tēkhne] but as a mediating practice of being "held fast" [ekhein] by the Muse. Like the Heraclean stone, poetic evocation is explained as a "long chain" of rings: the first ring [prētoi daktulioi] is Homer, which is connected to the middle ring, being lon, which is connected to the last ring, being the spectators [theatai]. Let us look a bit more closely at the logic behind the analogy:

\begin{abstract}
For this stone not only attracts iron rings, but also imparts to them a power whereby they in turn are able to do the very same thing as the stone, and attract other rings; so that sometimes there is formed quite a long chain of bits of iron and rings, suspended one from another; and they all depend for this power on that one stone. In the same manner also the Muse inspires men herself, and then by means of these inspired persons the inspiration spreads to others, and holds them in a connected chain. For all the good epic poets utter all those fine poems not from art, but as inspired and possessed. (533d-e)
\end{abstract}

The performing rhapsode is, according to Socrates, a link in a transmission chain, which is based on a dynamic of inspiration transferred from ring to ring, which initially moves top-down, so to speak: there is a divine power in the form of the Muse on top, which possesses the poet (Homer in this case), which transfers divine power to lon on stage, who channels that inspiration through his reciting and infects the audience with his intoxicated nature. There is thus a link between rhapsodic performance, magnetism and the idea of intoxication. Ion magnetizes the audience with his ecstatic performance, who will then be spiritually contaminated with the divine, similar to a contagious poison. It is precisely the performative power of bringing people in high spirits that Plato will use to regard rhapsody as an irrational endeavor. In the dialogue, Socrates forces (or ironically seduces) Ion in admitting that finally his practice is neither based on theoretical (epistēmē) or practical knowledge, craftmanship or skill (tekhne) , nor on interpretation or creative expression but on sole transmission: he is just one link in a chain, as is Homer and the audience. Crucially, indeed, the spectators are not outside or opposite the performance but equally partake in the magnetic chain of transmission; "your spectator is the last of the rings which I spoke of as receiving from each other the power transmitted from the Heraclean lodestone" (535e). Simply on the basis of the divine powers that translate through the attraction of the Muses alone, one cannot truly distinguish between the affected roles of poet, spectator and performer. All involved are equally equipped and devoted to becoming contaminated by a 'higher ring' (Murray 1996, 123). Or, as Prashant Bagad put it: "the experience-and the understanding of the world inherent in, or accompanying, that experience-that the poet has, is not different in kind from the experience that the rhapsode and an audience undergo" $(2016,258)$. All participants seem to be under the same spell of passive intoxication.

Rhapsodic performers are mediums, they are deprived of reason "in order that we who hear them may know that it is not they who utter these words of great price, when they are out of their wits, but that it is God himself who speaks and addresses us through them" (Plato 2014, 534d). To 
anticipate Plato's later phrase in Book 10 of the Republic in which he classifies the poets as producing copies of copies-"they're three stages removed from reality" (Plato 2013a, 599a)-Ion is a transmitter of a transmitter, or an "interpreter of an interpreter" (Plato 2014, 535a). His mind, body and soul are completely intoxicated by Homer's verses: "For I will tell you without reserve: when I relate a tale of woe, my eyes are filled with tears; and when it is of fear or awe, my hair stands on end with terror, and my heart leaps" (535c). As this movement is based on a doctrine of enthusiasm (from Greek en-theos, in-God; i.e. to be possessed by the gods, to be in ecstasy) no intellectual operation or critical analysis could intervene in this flow. At least not in the obvious, reflective, manner. This counts for all parties involved. It is important to emphasize once more that the analogy with the Heraclean lodestone enables Socrates to give an account of the performer as a fundamentally decentered figure. His practice is only intelligible when understood in its undertaking in light of a poetic sphere that partly transcends him or her.

Ion agrees more or less with everything that Socrates has argued so far except for one point. He shares with Socrates the idea that in order to move the audience he must surrender to the divine powers at work in Homer's Iliad and Odyssey. His technai are harmony, meter and rhythm, much like in a spectacle of worshipping, rather than reason or artistic crafting. Ion is not convinced, however, that his intoxication reduces him to a madman (p. 536 d-e). In order to convey his point, Ion draws attention to his connection with the audience, which is, according to him, necessarily dual. Let us dissect that duality on the basis of the passage where lon subtly and subversively intervenes into Socrates' 'monologue'. Socrates suggests that the magnetic force, the power that links lon's ring with the ring of the audience, results in spectators imitating lon's emotional expressions while watching him: "And are you aware that you rhapsodes produce these same effects on most of the spectators also?" (535d). Ion agrees but adds a fundamental supplement to this discovery:

\footnotetext{
Yes, very fully aware: for I look down upon them from the platform and see them at such moments crying and turning awestruck eyes upon me and yielding to the amazement of my tale. For I have to pay the closest attention to them; since, if I set them crying, I shall laugh myself because of the money I take, but if they laugh, I myself shall cry because of the money I lose. (535e)
}

Ion claims to undergo extreme emotional episodes but, in the meantime, also checks whether these evocative affairs produce the desired effects in the audience. How can one be fully intoxicated by the divine and at the same time overcome that state in order to observe and evaluate the transformations of the spectators? This double act entails two things. First, it means that the dynamic of intoxication, as explained by Socrates on the basis of the metaphor of the magnet, moves not only 'downward' but also 'upward', in the sense of the audience sending divine inspiration back, not all the way up to Apollo, but at least up to the rhapsode. Second, the magnetic force goes both ways but only with respect to the act of the rhapsode. It is only lon's ring that is capable of introducing and maintaining the magnetic chain in terms of securing its two-way dynamic. In order to accomplish this, it is required of him that he performs that paradoxical double bind: to be "held," "possessed" by higher powers (536b), while retaining the critical capacity of 
observing the audience and assessing their emotional expressions. In turn, lon understands his own divine affection as the necessary condition for the spectator's discovery of Homer's genius. More elaborately even, in and through the embodied expression of Homer's poetry, Ion apprehends himself and is conceived by the audience as the instigator of divine powers at work in the audience and takes responsibility for its success and failure. According to lon, mastering this double bind is neither based on natural talent nor on practical craft shared by all artists but is unique to rhapsodic performance.

Homer the poet is purely and solely inspired by his Muse. He does not have to worry about the performative possibilities of his verses nor with the manner in which the theatrical (or educational) materialization of his text intoxicates the audience. As long as the poet is inspired, he can create. He does not need that dual role in the chain in order for his work to come to completion. One could argue, by distinction, that the rhapsode must always receive the magnetic force back from the audience in the form of facial expressions, gestures or perhaps an affirmative or dismissive exclamation every now and then to be able to continue his/her performance. The fact that spectators are an important source of information and inspiration for the rhapsode is not a secondary issue. Ion would simply be out of work if he failed to accurately perceive and translate the audience's responses.

Socrates made a real effort of explaining rhapsodic reciting as an all-encompassing, contaminating practice in which all participants are connected with one another. The power of Homer's verses in terms of being affected by them on an emotional level is made possible by the condition of transmission: a force of inspiration that travels from one party to another. Socrates and lon agreed that Ion and the audience share the experience of being filled by the divine. Moreover, if Ion succeeds in his task, he will see his own transformations imitated in the audience. This insight suggests that the so-called protean nature of Ion does not belong to lon alone but is equally transmitted to or already at place in the audience members. In fact, this nuance can be found in the short passage we reviewed earlier: "For this stone not only attracts iron rings, but also imparts to them a power whereby they in turn are able to do the very same thing as the stone, and attract other rings" (Plato 2014, 533d; my emphasis). In other words, the audience appears emotionally affected by Homer's beautiful poetry but is equally apt to transfer those affects to others. Surely, Ion's performance would not have such an impact if it did not also presuppose the malleability of an audience. But why, in contrast to lon, do spectators not consider themselves participants in the play, even though they are equally considered transmitters of affects? This brings me to a second remark.

Socrates argues that lon's role consists in channeling Homer's genius without the interference of knowledge, skill or science. This seems to imply that practically anyone could replace him. The opening of Ion, however, indicates quite the opposite: Socrates meets his interlocutor shortly after his return from Epidaurus, where he won first prize in a competition (agōn) of rhapsodes. There is something special about Ion. In fact, Socrates acknowledges that he is dealing with someone who knows what he is doing. Hence, the irony of the dialogue cuts both ways: Socrates' suggestive argumentation forces Ion into a position of ridicule and folly. However, the fact that he invests so 
much time and effort in dissecting lon's practice expresses a deeply rooted interest in the man behind his many forms. Moreover, the dialogue ends so abruptly that lon's final agreement seems to be more of a friendly (albeit naive) gesture than a philosophically valid confirmation of what was being argued as Ion's most serious objections are ignored. Moreover, the irony of the text places "Socrates on the stage," as Puchner would argue (Puchner 2010, 37-72). The indecisiveness of the dialogue's philosophical stakes makes-visible Plato as the writer of a sort of play where the characters of Ion and Socrates are evocative figures designed for animating the reader.

As Penelope Murray explains, Ion's objections boil down to the distinction he tries to make between the factual content of Homer's poetry and its expression (Murray 1996, 130). Ion's talent lies in his ability to judge what performative voice each character requires in order to achieve the most emotional impact on the audience. The latter is a proper skill according to Ion (rhapsēidikē tekhnē, rhapsodic craft), and includes creative use of diction as well as what we nowadays would perhaps call emotional intelligence (as opposed to only logos or content). This expertise enables him to map out, converge and contrast his own expressions with those of the spectators. For this, Ion indeed does not need any factual knowledge about how the horseman treats his horse or how the fisherman throws his fishing net in the sea. But if the sailor, while sailing, is suddenly overcome with divine powers when hearing the unearthly voices of the Sirens, lon surely needs to know what a sailor sounds like when being in such a state. Impersonating the Sirens' singing as well as the sailor's modes of intoxication requires of lon taking on different characters or shapes (even if the rhapsode's performative genre is still that of reciting). Furthermore, on an actor's level, he has to be able to change pace, melody and intonation if people in the audience laugh at him because he appears ridiculous instead of tragically moved. Socrates fails to see or purposefully decides to ignore these skills.

Now that we have mapped out the performative layers of Ion's intoxicating rhapsody we can conclude, provisionally, that there is a paradox (from Greek paradoxon, para- 'contrary to' and doxa 'opinion', i.e. contrary to common belief) underlying lon's act of performing. The dual nature of Ion's performing appears as a paradox, specifically when assessed against the background of Plato's views on rhapsody. Plato presupposes that being possessed by the Muse--like in the case of rhapsodic performance--necessarily excludes being in control. This view is not that far removed from our common belief regarding the idea of possession: you cannot be 'in-god' and 'with the world' simultaneously; being in ecstasy entails that one is lifted out of oneself and reaching a state of pure transcendence. One might say that the very essence of being possessed is to lose oneself, which entails losing touch with the world. Contrary to this common belief, Ion argues that these two modes can in fact co-exist. Being inspired by Homer's genius via the Muse is not contrary to enacting a well-crafted emotional scene on stage with necessary distance.

In the Ion, we have witnessed lon's own awareness of this paradoxical state, despite Socrates' efforts to silence developing this issue further. The main aim of the second part is to pull apart, conceptually, the logic of paradox. It will enable us to address performative intoxication as not only passive but also inherently critical and distant, that is, a potential source for intervention. There are a few central questions at play. How can a performer distance himself/herself from his/her 
intoxication considering that he/she is his/her own 'material'? How can lon passively undergo the intoxications of his Muse and actively (re)present them? What is the role of the opposition between passivity and activity in relation to impersonation? We will analyze these issues following Diderot's analysis of the actor's paradox. Diderot's dialogue is helpful because it emphasizes the importance of the distinction between being and appearing. Indeed, Diderot conceptualizes, philosophically, where lon seemed to be alluding to all along: an actor can represent emotions and/or characters without necessarily identifying with them (against the style of Romantic self-expression, for example). As Diderot explains, inspiration is necessary but only in so far as the actor proves capable of channeling that affection in terms of providing a set of theatrical signs (gestures, speech, facial expressions, etc.) that enable the spectators to be absorbed in the emotional live of the character (in contrast to Brechtian theatre, which aims at an alienation effect in the audience). This requires technique, experience and insight in the human condition. In order to develop this issue further I suggest we take a look at three central notions in Diderot's Paradox, namely, sensibility (sensibilité), the ideal imaginary model (le modèle ideal imaginé) and judgement (jugement). This will provide the conceptual basis for assessing the paradoxical intertwinement between inspiration or possession ('passive'), on the one hand, and critical distance ('active'), on the other. Finally, we will turn to Lacoue-Labarthe's deconstructive reading of Diderot in order to show that the very distinction between being passively written, on the one hand, and actively writing, on the other, is subjected to its very own theatre (i.e. logos), namely what he calls, following Diderot, the "theater of life" (Lacoue-Labarthe 1989, 264).

\section{Ion, Diderot's actor and productive paradox}

In Diderot's famous phrase of the actor's paradox, "the great actor is everything and nothing" (1957, $41)$, the nothing refers mainly to the absence of sensibilité. Sensibilité represents for Diderot a totality of hypersensitive modes that originate in and around the diaphragm and which possesses someone's entire being:

\section{But what is a being possessed of sensibility? One abandoned to the mercy of his diaphragm; should a pathetic phrase strike his ear, a strange phenomenon meet his eye, of a sudden an inward tumult is set up, all the fibers of the bundle are agitated, a shudder runs through his frame, he is seized with horror, his tears flow, sighs choke him, his voice breaks, and the origin of the bundle does not know what it is doing: farewell to self-control, reason, judgement, instinct and resourcefulness. (Diderot 1999, 127)}

Central in this fragment is the idea of becoming 'under the spell of' the movements of one's diaphragm. According to Diderot, sensibilité is an all-embracing state in which body and soul are taken over by impulses that originate in the in the midriff area, and are so powerful that they paralyze reason. It is important to note that for Diderot sensibilité does not equal feeling. The latter is a momentary state that an actor can easily distance himself/herself from or transform into an affective sign that fits the theatrical role. In fact, the ancient notion of magnetic enthusiasm as well as intoxication, which we saw discussed in the Ion, describes perfectly what Diderot has in mind 
and he frequently uses these terms analogously to sensibilité; "he will bear you down with his fire and the intoxication of his emotions", "Cool reflection must bring the fury of enthusiasm to its bearings" (Diderot 1957, 17, 64). According to Diderot, enthusiasm is what characterizes mediocre actors: they throw themselves passionately into the role, are taken away by their desire for personal expression and completely forget about the aesthetic framework in which they operate. For Diderot, great acting is characterized by coherence and continuity of the role, which requires distance and reflection. If an actor is merely "at the mercy of his diaphragm" (Diderot 1999, 127), his performance might be brilliant one time but absolutely atrocious at other times (Diderot 1957, 12).

It seems as if Socrates wants to make of Ion a victim of what Diderot considers a problem of sensibilité. Clearly, in the case of rhapsody the intoxicating dynamic is a result of divine inspiration, not the actor's diaphragm as is the case in Diderot. In Diderot, enthusiasm refers to the actor's desire for self-expression, while, with lon, it is the Muse who inspires or enthuses the performer. Despite this significant difference, Socrates' description of Ion's intoxicated rhapsody is strikingly similar to what Diderot detests in "the man of sensibility"' (Lacoue-Labarthe 1989, 263). How so? On the basis of the Heraclean stone, Socrates is able to account for divine power as an engendering mechanism: it has the ability to equally transfer the power of attraction to 'rings' outside itself. This dynamic is based on magnetism, infection or contagion, which works autonomously and most importantly disables the powers of reasoning. Just as "worshippers do not dance when in their senses" (Plato 2014, 421), the rhapsode is, according to Socrates, the mere embodiment of divine affections. Lacoue-Labarthe points out in that regard that the ancients and moderns tend to postulate enthusiasm and intoxication as equal to passion and passivity, connecting it to "possession, delirium, hysteria, and collective mania", and "femininity" (for ancient precursors of "hysteria," see King 2006; Lacoue-Labarthe 1989, 263; Diderot 1957, 18). Ion is convinced that he is not at all a victim of this kind of intoxicated madness and argues that his expertise (rhapseidike tekhne) requires hard work and 'know-how' about the dramas of Homer's characters. Indeed, his position comes much closer to the pragmatist approach that Diderot favors in detached actors; actors who base their practice on observation, experience, judgement and labor are truly sublime. In that sense, Diderot would applaud Ion's rhapsodic craft.

The first sign of the paradox appears when we dissect the notion of intoxication. Both the sublime actor in Diderot and the rhapsode in Plato characterize their performing in terms of being intoxicated by something other or foreign. At the same time they claim to have self-control, "stillness and self-command" (Lacoue-Labarthe 1989, 262). The Muse is Ion's 'other'. In Diderot, the great actor is-in contrast to the mediocre actor who is possessed by the movements in his/her diaphragm-intoxicated by his/her so-called imaginary model (le modèle idéal imaginé). The artistic model is a perfected imaginary figure, a "phantom," that is created by the actor during rehearsals, which functions as an artistic beacon or reference point for future performances (Diderot 1957, 40). This model only 'exists' insofar as the actor integrates it in and activates it through his/her bodily and psychic transformations. The phantom-figure does not pre-exist the theatre scene and it does not 'reside' somewhere in a transcendent (e.g. divine) realm. Furthermore, the model molds the actor but this does not result in a fixed state of being: the actor's materialization of the model 
keeps changing in light of new information. Importantly, the model is not a mental image or picture in one's head but more like a unity of several (epistemic, emotional, psychological, practical, aesthetic) layers that capture the role's essence, and of which the actor becomes the physical expression. In order to give voice to the grandeur of the imagined figure, the performer has to be absolutely devoted to it and keep it in mind at all times. It is this dynamic engagement with the imaginary model that Diderot's performer is intoxicated by. For Diderot, being infatuated by an ideal imaginary refers to an active and creative use of memory, imagination, hard training and a clear mind. Thus, for Diderot, actors are not passive, and neither were the rhapsodes, according to Ion. In any case, this aspect of Diderot's paradox designates the possibility of being molded by something foreign (the model), where the model does not give the self a form but, rather, enables the self to become something completely fictive, imaginary, "a pure no one" (Lacoue-Labarthe 1989, 264).

Let us zoom in on the latter statement. The imaginary model not only functions as the ongoing motivator for the creation, interpretation and presentation of the role, but also enables the actor to forget about himself/herself: it presents him/her as a 'nothing'. It is only when the model is well designed, that is to say, when it provides the creative tools for the engendering of a stage persona, that the actor can become nothing and thus potentially everything. This is Diderot's central thesis. Again, this double act is not passive but requires judgement (jugement). What kind of judgement does Diderot have in mind? Lacoue-Labarthe points to an example that Diderot gives in the Paradox, namely the case of Clairon (one of Diderot's favorite actors), which clarifies the issue at hand:

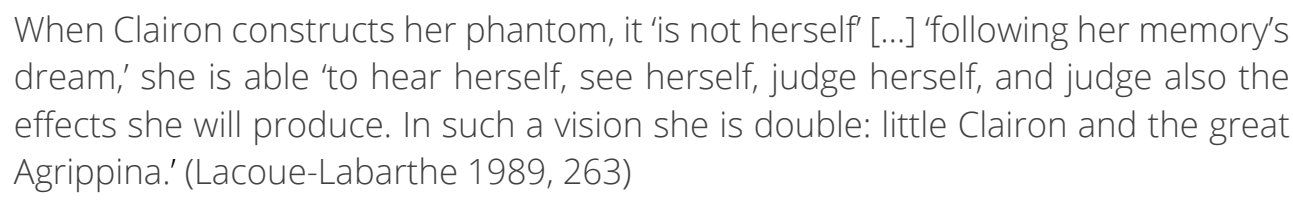

Clairon's "vision" of her "phantom" performs the following act: the negation of the mundanity of her 'private', 'everyday' self (the fact that she is lying on a couch while she is envisioning her phantom, for example) is the necessary condition of the projection of the self against the background of one's past, present and future enactments of the phantom. Being intoxicated by the ideal imaginary implies a mechanism of self-forgetting, which in turn enables the actor to judge his/her impersonations from a third-person perspective and in light of the model. In sum, the model puts in motion a 'machinery' of fictioning - or as Jacques Derrida calls it in one of his footnotes in Dissemination, "a mimetological 'machine"' (Derrida 2007, 190)—which makes of the performer the playfield of both (active) judgement and wisdom as well as (passive) intoxicated material signifying nothing.

This insight sheds an interesting light on lon's practical view on rhapsody. When lon revives Homer's poetry, he activates an intoxicating dynamic that is, much like Diderot's imaginary model, based on craft, reflection and judgement. Moreover, the example of Clairon brings another crucial similarity with the rhapsode to the surface, namely the inclusion of the spectator. It is only on the basis of positing oneself in light of an ideal type-or in the case of Ion, the Muse-that one can 
judge (a) the aesthetic value of one's own performance and (b) how one's performance affects the audience. There is a necessary, double alienation at play, which makes rhapsody a joined experience with the audience. This is crucial because it is the performer's responsibility to make every member of the audience complicit in these self-alienating, intoxicating workings. But, to rephrase my earlier question, how can one actively posit oneself as a project of self-alienation? How does this paradoxical play of passive and active forces affect the audience and, finally, result in intervention? In order to assess this issue, we have to look at the conditions of self-presentation, for which we will turn to Lacoue-Labarthe.

\section{Lacoue-Labarthe, paradox and impersonation as intervention}

There are two central theses in Lacoue-Labarthe's essay, 'Diderot: Paradox and Mimesis', which originally appeared in Poétique (1979), later collected in L'imitation des modernes: Typographies II (1986) and available in English in Typography (1989), that help us explain what kind of constitution of the self we have to presuppose in order to account for, on the one hand, intoxication as a passive undergoing of fictive models and, on the other, intoxication as an active, creative, productive mode. As we saw in Plato's Ion and Diderot's Paradox, the performer's concrete practice on stage does not allow for a mutual exclusiveness of the two modes: they imply one another. The actor must receive, i.e. channel, the model's creative force but equally present himself/herself as responsible for the proper working of the model. Lacoue-Labarthe's first thesis regards the subject's receptiveness for models and is based on a deconstructive take on the philosophical notion of mimesis. On the basis of a critical examination of the Platonic idea of imitation as imprinting the soul in Republic Book II and III, Lacoue-Labarthe will account for the self as in se plastic. The second thesis builds on the first in that it explains how the self as 'malleable wax' is to be explained, namely as a continuous interplay between passive and active mimesis. Ultimately, Lacoue-Labarthe understands the constitution of the self as a play, a theatre, a comedy to be performed. This insight will finally enable us to evaluate intoxication as an actor's strategy to intervene in the logos of the world. But before we come to our concluding notes, let us elaborate on Lacoue-Labarthe's theses.

Lacoue-Labarthe shows that the idea of the intoxication of the self, of being "imprinted" with models, as he would say, goes back (again) to Plato and, more specifically, his concern regarding the molding of the souls of young children: "Things begin [...] with the impression of the type and the impression of the sign, with the mark that language, 'mythic' discourses [...] originally inscribe in the malleable - plastic - material of the infant soul" (Lacoue-Labarthe 1989, 126). It leads us too far to discuss Plato's original theory of the soul here. What is especially important for our analysis is the idea of the human soul being a so-called "tabula rasa", an unwritten slate, which is a term coined by Aristotle, but that can be traced back to Plato's Republic Book II, which deals with the role of stories and models in education (Plato 2013b, 377a-383c). Plato's argument is that initially the child is considered neutral, blank, malleable material: "You know that the beginning of everything we undertake is most important, especially in any young tender creature? That is when it is most malleable and when whatever character you desire to be stamped on the individual is fixed." (Plato 2013b, 377a) Growing up, the child will be formed, shaped, "in-seminated" (in Lacoue-Labarthe's 
words) by parental and societal representations of the gods, myths, historical tales, fables, and images (Lacoue-Labarthe 1989, 127). According to Plato, the model that shapes the child can, at least initially, be neatly distinguished from its neutral, 'basic' material. Lacoue-Labarthe points out that this presupposition is crucial for Plato because it enables him to develop his views on how a community should be created: the city rulers (philosopher-kings or guardians) are in charge of the education of citizens. Together with their helpers, they proactively shape young children far into their adulthood with models that represent the Just and the Good. Ideally, these educators know what an ideal society looks like and will, accordingly, choose the stories, types and figures that represent the citizens desired.

Lacoue-Labarthe emphasizes that Plato's distinction between the human soul as tabula rasa, on the one hand, and the act of imprinting models onto that blank slate (by poets and teachers alike), on the other, assumes an opposition between "activity and passivity" (Lacoue-Labarthe 1989, 126). Plato's idea of the making and shaping of citizens works on the basis of a conceptual distinction between receptacle wax that is passive and external 'hands' that actively mold the wax. Moreover, Plato's model hints at a teleological mimesis: we start with passive youngsters who will, with the help of well-informed external parties, slowly but surely become rational, moral agents, each individual earning their proper place in the ideal city. In Lacoue-Labarthe's reading, this presupposed opposition and teleology underlying mimetic practices are products of Plato's implicit desire to eliminate what remains unformed and equivocal. Lacoue-Labarthe will question whether there is not always something in the act of imitation that resists full identification with the represented models.

What is at stake for Lacoue-Labarthe is not to refute Plato's views on the interrelation between malleability and mimesis. Rather, he wants to argue that despite the subject's imitation of models and figures, which is in a way inevitable because of our inherent mimetic tendencies, the subject will remain malleable and unstable. He reformulates this claim in terms of the subject as lack: lacking substance, properties, character. In a sense, he applies Diderot's central claim in the Actor's Paradox (of the genius actor being essentially nothing) to the constitution of the self as such. Moreover, he characterizes the subject's lack of qualities as a "gift" in the sense that it enables the subject to become the 'author' of mimesis himself/herself and potentially the source of resistance: "For inasmuch as it implies a subject absent from itself, without properties or qualities, a subjectless subject, a pure no one, mimesis is by definition (so long as one is not frightened by it in advance) active" (264).

In the context of Lacoue-Labarthe's deconstruction of Plato's model, let us return to the theatre. How do these critical notes relate to the actor's practice and what kind of resistance and intervention does it account for? Lacoue-Labarthe's philosophical position—one must be careful here as Lacoue-Labarthe purposefully backs away from making any philosophical claims himself; he characterizes his proceedings as no more than "rigorous hesitations" (Lawtoo; Ronell 2012, 262)-has undoubtedly always been informed by his love for and practice in the theatre. This is why the experience and pure excitement of "passer au théâtre" (see Bianchi; Kharlamov 2017) should play an integral part in our investigation. Let me first briefly summarize what we have 
discussed so far. In line with Plato and Lacoue-Labarthe, one could say that the subject's malleable nature makes it impossible to not be constantly influenced by, 'figurated', and imprinted on by models (one can even think of models in terms of representations of gender, class, status, etc.), but Lacoue-Labarthe urges us to not take the logos of a (external, active) weaving of the fabric of a (passive, receptive) subject at face value (see his deconstruction of Plato). There is the risk of a philosophical impasse. Either we are completely in possession and the mere product of powers that exceed our understanding, in which case we indeed take intoxication to be passive. The other option is embracing the self as an unbound, fluid substance that can be perfected according to the models 'we' please, which implies that our imitated models fully overlap with our sense of identity.

It is not a coincidence that Lacoue-Labarthe turned (again) to Diderot for a 'way out' of this impasse (although it is my formulation of the problem not his). There is a decisive performative turn in Diderot's dialogue. At a critical point in the discussion about the actor's paradox, Diderot lets his interlocuters suspend their arguments and sends them off to the theatre; "our two talkers went to the playhouse" (Diderot 1957, 65). Lacoue-Labarthe points out that here, Diderot, the philosopher, takes up the role of the actor: "Diderot plays the theater: a second theater within the theater of the world, a re-theatricalization of the 'comedy' of the world"' (Lacoue-Labarthe 1989, 265). For LacoueLabarthe, this is one of Diderot's playful (and philosophical) moves to show that there is a limit to theorizing the actor's practice. It reveals that simply deciding whether the actor is passively subdued or forms himself/herself actively, cannot be 'solved' theoretically. The decision is pure speculation as long as one is not oneself affected by its performative effects, which is why Diderot suddenly presents himself as the 'actor' or author of the dialogue. In so doing, Diderot seems to suggest that the experience of the theatre, be it as performer or spectator, refuses to decide on the matter once and for all. This explains Diderot's insistence on the logic of paradox. As LacoueLabarthe put it in one of his essays, "theatre is too brutal, too pitiless an art. It allows of no 'approach"' (Lacoue-Labarthe 2007, 203; McKeane 2015, 155). Jane Bennett points out in that regard that "every act of artistic mimesis will differ from all blueprints and inspirational ideas and dreams, insofar as the creative process always differs from itself as it proceeds" (Bennett 2017, 1198). Going (back) to the theatre is therefore a sort of imperative for Lacoue-Labarthe. It is precisely the paradox of coincidence and noncoincidence of the "scenic gesture" with itself (Kirkkopelto 2009) that connects the unstable status of the subject, mimesis, philosophy and the theatre with each other.

What emerges out of this comparison is then the active play of critique and mockery. It is important to not lose track of the experiential foundations of this insight. In and through our spontaneous grasping of the performer lon as the embodied playfield of passive and active forces-intoxicated, yet in control-a horizon, or scene, of possible relations opens up. This horizon is shared by all spectators and allows for every individual to be affected by similar as well as different relations between the active and the passive (between typing and being-typed). In order to be truly touched by a theatrical scene, we have to have presented, 'announced' ourselves as the willingness to give up or suspend our need for deciding on our identity. In other words, there is a collective selfabandonment that allows for identification and which results in a joined intoxicated experience. This entails putting ourselves at the service of the paradox at play in the performer's modes of 
impersonation. Yet, this kind of identification does not equal the passive undergoing of 'outside' forces but designates one's temporary involvement in playing along with mimesis. This means a disruption of the dominant logos of the passive / active dialectic of which Plato's conception of mimesis in the earlier books of Republic is but one example.

The performer shares with the audience the play of passive and active forces. The relations themselves are, however, in the case of Ion, subordinated to the workings of his impersonations via the Muse's doings. It is precisely because he can maintain a critical distance to his imitation of models and characters, by way of persistently positing himself as a nothing, that he is able to share with the audience in the genius of Homer, the Muse and divine power. It is crucial to see that lon's role is distinctive in so far as only he is able to do the workings of the paradox (just as only Diderot was in the position to distance himself from his own philosophical discourse). Precisely on this point we start to grasp the potential of considering the figure of Ion as a philosophical and aesthetic intervention strategy (Lacoue-Labarthe 1989, 265). His staging of the paradox - of being nothing and everything, passive and active, shaped and shaping, affected and distant-is the living exemplification of the philosophical and aesthetic becoming interchangeable. Ion is exceptional because he masters the play of the passive / active dialectic underlying (philosophical) discourses, ridiculing the assumption that mimesis forces one in a position of mere passive intoxication. In that way, lon intervenes in and mocks the logos that the theatre of the world represents. His practice reveals that the image of subjects imitating models pure and simple is not necessarily a bad representation of the world but, rather, that it presents the world of "bad theater" (264).

\section{Works Cited}

Bagad, Prashant. 2016. "The Riddle in Plato's Ion." Journal of Indian Council of Philosophical Research 33 (2): $253-$ 264. https://doi.org/10.1007/s40961-016-0041-2

Barish, Jonas. 1985. The Antitheatrical Prejudice. Berkeley: University of California Press.

Bennett, Jane. 2017. "Mimesis: Paradox or Encounter." MLN 132 (5): 1186-1200. https://doi.org/10.1353/mln.2017.0091

Bianchi, Aristide, and Leonid Kharlamov. 2017. "Passer au théâtre." L'Esprit Créateur 57 (4): 10-21. https://doi.org/10.1353/esp.2017.0037

Corby, James. 2015. "The Contemporary Quarrel Between Performance and Literature? Reflections on Performance (and) Philosophy." Performance Philosophy 1: 36-50. https://doi.org/10.21476/PP.2015.1112

Cull, Laura. 2012. Theatres of Immanence: Deleuze and the Ethics of Performance. Basingsotke: Palgrave Macmillan. https://doi.org/10.1057/9781137291912

Derrida, Jacques. 2007. Dissemination. Translated by Barbara Johnson. Chicago: University of Chicago Press.

Diderot, Denis. 1957. The Paradox of Acting. In Denis Diderot: The Paradox of Acting; and William Archer: Masks or Faces? New York: Hill and Wang

1999. Thoughts on the Interpretation of Nature and Other Philosophical Works. Translated by Jean Stewart and Jonathan Kemp. Manchester: Clinamen.

Gebauer, Gunter, and Cristof Wulf. 1995. Mimesis: Culture, Art, Society. Berkeley: University of California Press. 
Girard, René. 1974. La violence et le sacré. Paris: Grasset.

King (Reading), Helen. 2006. "Hysteria." In Brill's New Pauly, Antiquity Volumes. Edited by Hubert Cancik and Helmuth Schneider. https://doi.org/10.1163/1574-9347_bnp_e520440

Kirkkopelto, Esa. 2009. "The Question of the Scene: On the Philosophical Foundations of Theatrical Anthropocentrism." Theatre Research International 34 (3): 230-242. https://doi.org/10.1017/S0307883309990034

Klooster, Jacqueline. 2011. Poetry as Window and Mirror: Positioning the Poet in Hellenistic Poetry. Leiden: Brill. https://doi.org/10.1163/ej.9789004202290.i-282

Lacoue-Labarthe, Philippe. 1989. Typography: Mimesis, Philosophy, Politics. Stanford, CA: Stanford University Press. 2007. "La fiction du biographique." Lignes 22 (1): 194-204. https://doi.org/10.3917/lignes.022.0193

Lawtoo, Nidesh, and Avital Ronell. 2012. "Postface: A Talk to Avital Ronell (about Philippe Lacoue-Labarthe)." In Conrad's Heart of Darkness and Contemporary Thought: Revisiting the Horror with Lacoue-Labarthe. Edited by Nidesh Lawtoo, 260-267. London: Bloomsbury.

McKeane, John. 2015. Philippe Lacoue-Labarthe: (Un)timely Meditations. New York and London: Routledge.

Murray, Penelope, ed. 1996. Plato on Poetry: Ion; Republic 376e-398b9; Republic 595-608b10. Cambridge: Cambridge University Press.

Murray, Timothy, ed. 1997. Mimesis, Masochism, \& Mime: The Politics of Theatricality in Contemporary French Thought. Ann Arbor: University of Michigan Press. https://doi.org/10.3998/mpub.10183

Nagy, Gregory. 2009. "Epic." In The Oxford Handbook of Philosophy and Literature. Edited by Richard Eldridge, 1944. Oxford: Oxford University Press.

Nails, Debra. 2002. The People of Plato: A prosopography of Plato and other Socratics. Indianapolis: Hackett.

Nancy, Jean-Luc. 2015. Intoxication. Translated by Philip Armstrong. New York: Fordham University Press.

Plato. 2013a. Republic, Volume II: Books 6-10. Translated by C. J Emlyn-Jones and William Preddy. Loeb Classical Library 276. Cambridge, MA: Harvard University Press.

2013b. Republic, Volume I: Books 1-5. Translated by C. J Emlyn-Jones and William Preddy. Loeb Classical Library 237. Cambridge, MA: Harvard University Press. https://doi.org/10.4159/DLCL.plato_philosopherrepublic.2013

_-_. 2014. Statesman. Philebus. Ion. Translated by Harold North Fowler and W.R.M. Lamb. Cambridge, MA: Harvard University Press.

Potolsky, Matthew. 2006. Mimesis. New York and London: Routledge. https://doi.org/10.4324/9780203401002

Puchner, Martin. 2010. The Drama of Ideas: Platonic Provocations in Theater and Philosophy. Oxford: Oxford University Press.

Rijksbaron, Albert. 2007. Plato, Ion or: On the lliad. Leiden: Brill. https://doi.org/10.1163/ej.9789004163218.i-292

Rokem, Freddie. 2017. "Theatrical Immanence: The Deus ex Machina after the Death of God." Performance Philosophy 3 (3): 781-793. https://doi.org/10.21476/PP.2017.33142

Rozzoni, Claudio, ed. 2013. "Forum on Martin Puchner, 'The drama of ideas."' Lebenswelt: Aesthetics and Philosophy of Experience 3: 110-153.

Tarde, Gabriel. 2010. The Laws of Imitation. La Vergne: Bibliolife. 


\section{Biography}

Niki Hadikoesoemo is a PhD candidate and a team member of the ERC funded project Homo Mimeticus: Theory and Criticism. Before receiving a BA, MA and Research MA in philosophy from the Institute of Philosophy at KU Leuven she studied at the Academy of Theatre and Dance, Amsterdam University of the Arts.

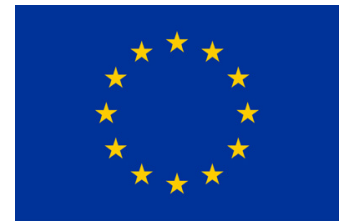

\section{$\because$ erc}

European Research Council

European Reseatished by the Euro

This project has received funding from the European Research Council (ERC) under the European Union's Horizon 2020 research and innovation programme (grant agreement $n^{\circ} 716181$

(C) 2020 Niki Hadikoesoemo

(c) (7) Except where otherwise noted, this work is licensed under a Creative Commons Attribution-

(c) Non Commercial-ShareAlike 4.0 International License. 